\title{
EFEKTIVITAS PROGRAM PENGEMBANGAN DAN PENGELOLAAN JARINGAN IRIGASI OLEH DPUPR DI KECAMATAN PAKISJAYA KABUPATEN KARAWANG
}

\author{
Windi Widyaningsih ${ }^{1)}$, Yamardi ${ }^{1)}$, Zaenal Abidin AS ${ }^{1)}$ \\ 1)Program Studi Ilmu Pemeritahan, Fakultas Ilmu Sosial dan Ilmu Politik, \\ Universitas Jenderal Achmad Yani, Indonesia
}

\begin{abstract}
Abstrak
Penelitian ini berjudul: "Efektivitas Program Pengembangan dan Pengelolaan Jaringan Irigasi Oleh Dinas Pekerjaan Umum dan Penataan Ruang di Kecamatan Pakisjaya Kabupaten Karawang". Fenomena yang terjadi di Kecamatan Pakisjaya adalah kekeringan irigasi. Permasalahan yang terjadi dalam penelitian ini yaitu Pengelolaan air jaringan irigasi di Kecamatan Pakisjaya tidak merata sehingga menghambat produktivitas petani yang ada di Kecamatan Pakisjaya. Metodologi penelitian yang dilakukan pada penelitian, yaitu deskriptif dengan pendekatan kualitatif. Teori yang digunakan adalah Efektivitas program menurut Makmur. Hasil penelitian menunjukkan bahwa efektivitas program pengembangan dan pengelolaan jaringan irigasi di Kecamatan Pakisjaya memiliki permasalahan dalam beberapa dimensi yang dikemukakan oleh Makmur sehingga, belum tercapainya efektivitas pada program tersebut. Hal ini dapat dilihat dari ketepatan waktu dalam pelaksanaan normalisasi belum sesuai, ketepatan perhitungan biaya yang dapat dilihat dari sarana dan prasarana kurang memadai, ketepatan dalam pengukuran dalam pelaksanaan tugas dan pertanggungjawaban belum tepat, ketepatan dalam menentukan pilihan sudah tepat dalam metode pelaksanaan kegiatan program, ketepatan berpikir sudah sesuai dalam memahami konsep dan metode mempunyai pedoman untuk memahami dan proses evaluasi dilakukan dengan baik, ketepatan dalam melakukan perintah sudah sesuai karena mempunyai kriteria tertentu dalam pelaksanaan program, ketepatan dalam menentukan tujuan belum sesuai karena dapat dilihat dari ketentuan dan peraturan sudah ada namun dilihat dari sisi pengawasan yang dilakukan oleh Dinas Pekerjaan Umum dan Penataan Ruang belum maksimal, ketepatan sasaran belum sesuai karena masyarakat Pakisjaya masih belum terpenuhi kebutuhan airnya.
\end{abstract}

Kata Kunci: Efektivitas Program, Kecamatan Pakisjaya, Pengembangan dan Pengelolaan Irigasi

\begin{abstract}
This study entitled: "The Effectiveness of the Irrigation Network Development and Management Program by the Public Works and Spatial Planning Agency in Pakisjaya District, Karawang Regency". The phenomenon that occurs in Pakisjaya District is drought in irrigation. The problem that occurs in this research is that the management of irrigation network water in Pakisjaya District is not evenly distributed, thus hampering the productivity of farmers in Pakisjaya District. The research methodology used in the research is descriptive with a qualitative approach. The theory used is program
\end{abstract}


effectiveness according to Makmur. The results showed that the effectiveness of the irrigation network development and management program in Pakisjaya District had problems in several dimensions put forward by Makmur so that the effectiveness of the program had not been achieved. This can be seen from the timeliness in implementing normalization is not appropriate, the accuracy of cost calculations that can be seen from the facilities and infrastructure is inadequate, the accuracy in measuring the implementation of tasks and accountability is not yet right, the accuracy in determining the right choice in the method of implementing program activities, accuracy thinking is appropriate in understanding concepts and methods has guidelines for understanding and the evaluation process is carried out well, accuracy in carrying out orders is appropriate because it has certain criteria in program implementation, accuracy in determining objectives is not yet appropriate because it can be seen from the existing rules and regulations but seen In terms of supervision carried out by the Public Works and Spatial Planning Office, it is not optimal, the accuracy of targeting is not appropriate because the people of Pakisjaya have not yet met their water needs.

Keywords: Program Effectiveness, Pakisjaya District, Irrigation Development and Management

\section{PENDAHULUAN}

Karawang merupakan daerah Kabupaten yang berada di Provinsi Jawa Barat. Secara geografis Kabupaten Karawang merupakan dataran rendah. Karawang biasanya sering dikenal dengan kota lumbung padi, karena daerah Kabupaten Karawang dikelilingi oleh lahan pertanian. Selain dikelilingi oleh sawah, Karawang juga dikelilingi oleh laut. Kabupaten Karawang berbatasan dengan Kabupaten Bekasi yang dibatasi oleh Sungai Citarum. Untuk mempertahankan Kabupaten Karawang sebagai kota lumbung padi, maka pertanian di Kabupaten Karawang perlu diperhatikan agar petani padi bisa terus memproduksi padi yang baik. Saat ini Kabupaten Karawang dikenal bukan hanya kota lumbung padi, tetapi sebagai kota industri karena banyak investor yang berinvestasi di Karawang. Tidak hanya para investor, namun banyak yang melakukan transmigrasi penduduk untuk mencari pekerjaan di Kabupaten Karawang. Kabupaten Karawang memiliki sumber air yang cukup dengan adanya irigasi, karena Karawang merupakan daerah dataran tidak bisa mengandalkan air hujan saja. Irigasi ini diperoleh dari bendungan Jatiluhur yang di Kelola oleh Perum Jasa Tirta II (PJT II). 
Penyediaan dan jaringan irigasi diatur dalam Peraturan Daerah. Kesatuan wilayah, tempat manusia dan mahluk hidup lain, melakukan kegiatan dan memelihara kelangsungan hidupnya. Peraturan Daerah Kabupaten Karawang Nomor 2 Tahun 2013 Tentang Rencana Tata Ruang Wilayah menjelaskan bahwa Kawasan pertanian merupakan kawasan yang diperuntukan sebagai kegiatan pertanian yaitu kawasan pertanian lahan basah, kawasan pertanian lahan kering, kawasan pertanian tanaman tahunan/perkebunan, perikanan, peternakan.

Kecamatan Pakisjaya merupakan salah satu daerah yang mempunyai lahan pertanian yang luas untuk itu air sangat diperlukan dan harus tercukupi kebutuhan untuk produktivitas petani. Kecamatan Pakisjaya memang sulit mendapatkan air bersih, sehingga sangat minim air bersih. Hanya irigasi dan sumur disetiap rumah yang menjadi kehidupan mereka. Fenomena yang terjadi di 3 Desa yang tersebut mengalami kekeringan sangat sedikit air yang mengalir, padahal di hulu sepanjang jalan Rengasdengklok dan Batujaya air irigasi sangat banyak bahkan penuh sampai banjir ke jalan raya. Hal ini yang menjadi pertanyaan di 3 Desa tersebut. Para petani terhambat produktivitasnya jika terus-menerus terjadi. Karena air hal yang penting bagi para petani di Kecamatan Pakisjaya. Permasalahan yang terjadi karena pengelolaan air yang tidak merata serta kegiatan normalisasi irigasi tidak dilakukan semua di Kecamatan Pakisjaya, bahkan kegiatan normalisasi irigasi ini hanya sampai ke Desa Tanjungbungin saja. Ada 4 Desa yang menjadi fokus penelitian untuk wawancara yaitu Desa Tanjungbungin dan Desa Tanjungmekar yang merupakan Desa yang berdampak kekeringan, kemudian Desa Solokan dan Desa Telukbuyung yang tidak berdampak kekeringan. 4 Desa tersebut merupakan Desa yang cukup luas lahan pertaniannya sehingga tepat untuk dilakukan wawancara saat penelitian.

Terjadinya kekeringan air irigasi di Kecamatan Pakisjaya. Permasalahan ini akan berdampak terhadap daerah karawang itu sendiri, karena Kabupaten Karawang merupakan lumbung padi. Berdasarkan media (BERSEKANEWS.id, 
2019) Di Kecamatan Pakisjaya ini banyaknya hektar sawah yang mengalami kekeringaan karena minimnya pasokan air dari saluran irigasi. Menurut Camat Pakisjaya, Irlan Suarlan S.STP S.MI pada saat dihubungi oleh salah satu media mengatakan bahwa permasalahan kekeringan didaerahnya disebabkan oleh dua faktor. Pertama disebabkan oleh minimnya pasokan air ke wilayah Pakisjaya, hal ini terjadi karena banyaknya saluran yang mengalami penyempitan. Kedua tersumbatnya irigasi oleh sampah.

Setiap program Pemerintah perlu dilakukan secara efektif agar mencapai tujuan yang diinginkan secara berkelanjutan. Program Pemerintah sebagai jalan untuk mengatasi permasalahan, namun dalam pelaksanaannya selalu ada hambatan-hambatan dalam kegiatan program tersebut yang menyebabkan program tidak berjalan dengan lancar. Suatu program dikatakan tidak efektif jika ditemukan masalah yang berkaitan dengan program tersebut. Siagian dalam jurnal (Listianingtyas, 2012) Efektivitas yaitu upaya yang dilakukan secara sadar dan rasional agar terciptanya ketetapan penggunaan berbagai sumber daya yang dimiliki oleh suatu organisasi sehingga memberikan manfaat dan meningkatkan kesejahteraan sesuai dengan tuntutan kehidupan masing-masing. Selain itu menurut Makmur (2015:2) efektivitas yaitu aktivitas dilakukan secara efektif yang mana didalam proses pelaksanaanya menggunakan ketepatan antara harapan yang diinginkan dengan hasil yang dicapai.

Definisi program menurut Undang-Undang RI Nomor 25 Tahun 2004 Tentang Sistem Perencanaan Pembangunan Nasional, menyatakan bahwa program yaitu instrumen kebijakan yang berisi satu atau lebih kegiatan yang dilaksanakan oleh instansi Pemerintah/Lembaga untuk mencapai sasaran dan tujuan serta memperoleh alokasi anggaran atau kegiatan masyarakat yang dikoordinasikan oleh instansi masyarakat. Dapat dikatakan bahwa program adalah suatu rancangan kegiatan yang dibuat atas keputusan bersama untuk dilaksanakan agar tercapainya suatu tujuan yang telah ditetapkan. Suatu 
program dikatakan efektif apabila usaha atau tindakan yang dilakukan sesuai dengan hasil yang diharapkan.

Jaringan irigasi adalah bangunan dan ukuran yang berfungsi untuk menyalurkan air irigasi dari sumber air lahan pertanian dan membuang kelebihan air dalam lahan pertanian. menurut Widjiharti dalam jurnal (Wibowo, 2018) Selain menyalurkan air irigasi dan membuang kelebihan air dipetak, adanya jaringan diharapkan dapat memanfaatkan air yang tersedia secara efektif dan efisien, adil dan merata, diberikan ke rawa-rawa lahan tersier dengan tepat, sesuai dengan kebutuhan pertumbuhan tanaman dan menghindari akibat negatif yang timbul oleh air berlebihan. Sementara itu, menurut Menurut Kordi K, \& Tancung (2007:27) Irigasi ialah wilayah yang dibentuk manusia untuk usaha yang dialirkan air selama diperlukan dan mendapatkan air dari jaringan irigasi. Bentuk serta ukuran irigasi disesuaikan dengan fungsinya. Dengan ini, peneliti dapat menyimpulkan bahwa Jaringan Irigasi merupakan suatu bangunan yang berfungsi dibuat dengan sengaja untuk mengalirkan air hingga ke hilir. Jaringan Irigasi bisa dikatakan sebagai pemasok air berbentuk pintu air, bendungan, waduk, dan lain-lain. Dalam hal ini jaringan irigasi perlu diperhatikan karena sangat penting untuk memenuhi kebutuhan masyarakat.

Berkaitan dengan penelitian ini maka memfokuskan pada "Efektivitas Program Pengembangan dan Pengelolaan Jaringan Irigasi Oleh Dinas Pekerjaan Umum dan Penataan Ruang Di Kecamatan Pakisjaya Kabupaten Karawang" teori yang digunakan dalam penelitian ini merupakan unsur-unsur efektivitas yang dikemukakan oleh Makmur (2015:7-9). Peneliti beranggapan bahwa pendekatan ini lebih terukur dalam pelaksanaan program.

\section{METODE PENELITIAN}

Penelitian ini menggunakan metode kualitatif, untuk mendalami pemahaman mengenai metode kualitatif seperti yang dikemukakan oleh 
Sugiyono (2020:9) bahwa Metode penelitian kualitatif merupakan metode penelitian yang digunakan untuk meneliti suatu kondisi objek yang alamiah, dimana peneliti ialah sebagai instrument kunci, teknik pengumpulan data dilakukan dengan cara trianggulasi (gabungan), analisis data yaitu bersifat induktif, dan hasil penelitian kualitatif lebih menekankan makna daripada generalisasi. Metode Penelitian deskriptif dengan pendekatan kualitatif yang digunakan dalam penelitian ini dipilih berdasarkan pertimbangan menganalisis penelitian tentang Efektivitas Program Pengembangan dan Pengelolaan Jaringan Irigasi Oleh Dinas Pekerjaan Umum dan Penataan Ruang di Kecamatan Pakisjaya, merupakan kondisi alamiah, maka dari itu harus dilakukan pengkajian serta penelusuran secara teliti dan lebih mendalam dan bukan menarik secara umum atas hasil yang di dapatkan. Metode penilitian ini lebih memperlihatkan analisis dari objek penelitian.

Menurut (Andriani, dkk 2020:116) Ada dua pokok yang mempengaruhi kualitas data hasil penelitian yaitu, kualitas instrument penelitian dan kualitas pengumpulan data. Dalam penelitian kualitatif, kualitas instrument penelitian berkenan dengan validitas dan reabilitas instrument serta pengumpulan data dengan ketepatan cara-cara yang digunakan untuk mengumpulkan data. Instrumen penelitian yaitu "penelitian atau alat penelitian adalah penelitian itu sendiri". Oleh karena itu peneliti sebagai instrumen juga harus "divalidasi" sejauh mana peneliti kualitaf siap untuk melakukan penelitian yang selanjutnya turun kelapangan. Validasi terhadap peneliti meliputi validasi terhadap pemahaman metode penelitian kualitatif, penguasaan wawasan terhadap validasi terhadap bidang yang diteliti, kesiapan peneliti untuk memasuki obyek penelitian, baik secara akademik maupun logistiknya yang melakukan validasi adalah penelitian sendiri, dengan cara mengevaluasi diri seberapa jauh pemahaman terhadap metode kualitatif, penguasaan terhadap teori dan wawasan terhadap bidang yang diteliti, serta kesiapan untuk bekal pada saat memasuki lapangan. 
Penelitian ini dilakukan di Kantor Dinas Pekerjaan Umum dan Penataan Ruang Kabupaten Karawang, Kantor Kecamatan Pakisjaya, masyarakat, petani, dan Gabungan Kelompok Tani (gapoktan) Pakisjaya. Teknik analisis data pada penelitian ini menggunakan teknik sebagaimana yang dikemukakan Miles dan Hubberman dalam Sugiyono (2020:132-142) yaitu Data Collection (Pengumpulan Data), Data Reduction (Reduksi Data), Data Display (Penyajian Data), Conclusion drawing (Kesimpulan).

\section{PEMBAHASAN}

Berdasarkan penelitian dengan Kepala Seksi Perencanaan Dinas Pekerjaan Umum dan Penataan Ruang bahwa pembagian pengelolaan irigasi, jika kurang dari $1000 \mathrm{He}$ merupakan kewenangan Kabupaten/Kota dan jika 1000-3000 He merupakan kewenangan Pemerintah Provinsi. Untuk itu saluran irigasi berada di $900 \mathrm{He}$, artinya kewenangan Kabupaten. Dengan adanya program citarum harum yang dilakukan oleh Pemerintah Pusat, maka Dinas Pekerjaan Umum dan Penataan Ruang Kabupaten Karawang mendukung program dari Pemerintah Pusat tersebut dan Dinas Pekerjaan Umum dan Penataan Ruang Kabupaten Karawang mempunyai program pengembangan dan pengelolaan jaringan irigasi. Dalam hal ini bahwa Program Pengembangan dan Pengelolaan Jaringan irigasi dengan melakukan normalisasi, pemeliharaan, dan rehabilitas saluran sekunder dan tersier.

Program pengembangan dan pengelolaan Jaringan irigasi merupakan program yang dibuat untuk meningkatkan keandalan jaringan irigasi. Pelaksanaan tersebut sesuai dengan tugas Bidang pengairan sebagai penyusun rencana dalam pengelolaan sumber daya air. Program pengembangan dan pengelolaan jaringan irigasi tercantum dalam Rencana Strategis Dinas Pekerjaan Umum dan Penataan Ruang Kabupaten Karawang 2016-2020 pada halaman 2. Program pengembangan dan pengelolaan jaringan irigasi adalah program rutin yang dilakukan oleh Dinas Pekerjaan Umum dan Penataan Ruang Kabupaten Karawang, secara teknis dijelaskan dalam 
penetapan kerja tahun 2017 batas-batas yang menjadi kewenangan Kabupaten untuk melaksanakan program tersebut salah satunya dilaksanakan normalisasi di Kecamatan Pakisjaya.

Untuk mengetahui analisis dan deskripsi pada bagaimana efektivitas program dan pengembangan jaringan irigasi oleh Dinas Pekerjaan Umum dan Penataan Ruang di Kecamatan Pakisjaya Kabupaten Karawang dapat dilihat hasil pada setiap dimensi yang digunakan dalam penelitian ini, yaitu sebagai berikut:

\section{Ketepatan Waktu}

Untuk mengetahui lebih jelas mengenai ketepatan penentuan waktu dalam pelaksanaan program oleh Dinas PUPR peneliti melakukan wawancara dalam dua indikator. Dua indikator ini mempengaruhi tercapainya waktu yang tepat dalam pelaksanaan program.

a. Waktu yang tepat

Wawancara dari 8 informan adanya perbedaan pendapat dari Pemerintah yaitu Kepala Bidang SDA, Kepala Dinas, Kepala Seksi Perencanaan, dan Camat Pakisjaya mengatakan sudah sesuai hal ini dapat dilihat dari waktu yang ada tersebut melihat situasional anggaran, terdapat kesamaan pendapat dari petani di Desa Telukbuyung waktu sudah sesuai karena proses pelaksanakan tersebut tepat pada kondisi yang seharusnya di normalisasi sedangkan menurut petani di Desa Tanjungbungin, Masyarakat, dan Gabungan Kelompok Tani bahwa waktu belum tepat karena dalam melaksanakan kegiatan program tersebut tidak disesuaikan dengan cuaca atau musim yang diinginkan petani. Seharusnya ada mekanisme yang jelas untuk dapat menyesuaikan waktu. Hasil Observasi yang diamati oleh peneliti bahwa waktu pada pelaksanaan normalisasi irigasi belum sesuai, yaitu normalisasi dilakukan pada musim hujan sedangkan pada rehabilitasi infrastruktur jaringan irigasi masih belum maksimal dan waktu belum tepat karena masih banyak infrastruktur yang belum diperbaiki.

Jika hasil wawancara dan hasil observasi yang dilakukan oleh Peneliti waktu belum sesuai karena belum adanya kejelasan waktu yang pasti untuk 
menjadi rutinitas pada program pengembangan dan pengelolaan jaringan irigasi. Waktu yang tepat diperlukan dalam efektivitas program yang dijalankan oleh Dinas Pekerjaan Umum dan Penataan Ruang Kabupaten Karawang, agar mengetahui konsistensi pada penerapan setiap program kegiatan pengelolaan dan pengembangan jaringan irigasi ini. Penyesuaian waktu dapat dilihat dari kondisi di lapangan, dalam hal ini sudah disesuaikan dengan kondisi di lapangan yaitu melihat layak atau tidaknya untuk dilakukan kegiatan pada program tersebut.

b. Cepat sesuai waktu yang ditentukan

Hasil wawancara dari 8 informan bahwa dari Pemerintah yaitu Kepala Bidang SDA, Kepala Dinas, Kepala Seksi Perencanaan, dan Camat Pakisjaya bahwa cepat sesuai dengan waktu yang ditentukan sudah tepat karena proses pengerjaannya sudah cepat, terdapat pendapat yang belum jelas yaitu dari salah satu petani di Desa Telukbuyung yang mengatakan kecepatan tergantung dari penyedia jasa sedangkan pendapat dari petani di Desa Tanjungbungin, Masyarakat, dan Gabungan Kelompok Tani bahwa belum tepat hal ini dapat dilihat dari adanya hambatan-hambatan pada proses pelaksanaan kegiatan sehingga menjadi lambat. Berdasarkan observasi yang dilakukan oleh peneliti bahwa cepat sesuai waktu yang ditentukan belum tepat hal tersebut bisa dilihat dari proses pengerjaan normalisasi yang lambat dan beberapa hambatan pada kegiatan tersebut dikarenakan banyak warung yang didirikan oleh masyarakat di sekitar jaringan irigasi dan banyaknya sampah. Pada pembangunan infrastruktur masih banyak yang harus ditanggapi dengan cepat untuk dilakukan rehabilitasi.

Pada indikator cepat sesuai waktu yang ditentukan maka hasil wawancara dan hasil observasi yang dilakukan oleh Peneliti menghasilkan belum tepat adanya hambatan-hambatan yang terjadi pada kegiatan normalisasi tersebut seperti banyaknya warung-warung yang dibuat oleh masyarakat atau lain hal yang menyebabkan kegiatan tersebut belum sesuai waktu pengerjaannya. 


\section{Ketepatan Perhitungan Biaya}

Ketepatan perhitungan biaya juga menjadi salah satu tolak ukur dalam keefektifan, bagaimana meminalisir biaya tersebut dapat dialokasikan sebaikbaiknya. Terdapat dua indikator pada dimensi ketepatan perhitungan biaya ini yaitu pemanfaatan biaya yang sesuai dengan pengalokasian dana sebaikbaiknya dan tersedianya sarana dan prasarana dalam proses pelaksanaan program.

a. Pengalokasian dana sebaik-baiknya

Dari hasil wawancara pada informan mengenai pengalokasian dana dengan sebaik-baiknya hanya pada pemerintah yaitu Kepala Bidang SDA, Kepala Dinas, Kepala Seksi Perencanaan, dan Camat Pakisjaya karena masyarakat tidak mengetahui mengenai anggaran pada kegiatan tersebut maka dari itu sudah sesuai hal ini dapat dilihat dari proses pelaksanaan yang baik dengan adanya koordinasi baik dari camat sampai kepada DPRD kabupaten untuk penganggaran. Berdasarkan observasi yang dilakukan bahwa adanya keterangan anggaran di setiap kegiatan program pengembangan dan pengelolaan jaringan irigasi ini, yaitu pada SPK dan RAB.

Pada indikator pengalokasian dana sebaik-baiknya sudah sesuai, peneliti menyimpulkan dari hasil wawancara dan observasi sudah tepat. Adanya transparansi mengenai anggaran harus dikomunikasikan dengan baik, hal ini sudah adanya transparansi dari berbagai pihak terlibat. Baik pada pengelola, pelaksana, dan pengawas. Pengalokasian dana disesuaikan dengan anggaran. Pada kegiatan program pengembangan dan pengelolaan jaringan irigasi ini pengalokasian dana sudah baik sebagaimana yang sudah tertera dalam RAB tersebut.

b. Tersedianya sarana dan prasarana

Berdasarkan wawancara dari 8 informan terdapat perbedaan pendapat dari Pemerintah yaitu Kepala Bidang SDA, Kepala Dinas, Kepala Seksi Perencanaan, dan Camat Pakisjaya bahwa sarana dan prasarana sudah memadai sedangkan 4 informan yaitu masyarakat, 2 petani dan gabungan kelompok tani prasarana belum tercapai secara maksimal. Karena masih ada 
beberapa penambahan pembangunan dan kerusakan-kerusakan harus segera diperbaiki. Hasil observasi peneliti mengamati hanya ada beberapa pintu air saja, itupun ada yang berjalan dan tidak. Kemudian pembangunan lanning disisi irigasi tidak tepat karena di tiap desa ada yang dibangun dan belum dibangun.

Dari hasil wawancara dan observasi dilapangan berkaitan dengan sarana dan prasarana pada jaringan irigasi perlu dilakukan. Dalam pembangunan infrastruktur yang dibangun sudah ada, tetapi masih belum sempurna. Seperti kerusakan-kerusakan pintu air perlu diperbaiki. Selain itu adanya penambahan-penambahan pintu air yang mana masih belum tersedia di setiap Desa. Selain itu infrastruktur untuk pertahanan air di area tanggul irigasi belum sesuai. Pembangunan infrastruktur juga perlu disesuaikan dengan kondisi irigasi.

\section{Ketepatan Dalam Pengukuran}

Adanya dimensi ketepatan dalam pengukuran ini untuk melihat apakah kegiatan tersebut sudah sesuai dengan ukuran yang direncanakan. Terdapat dua indikator untuk mengetahui ketepatan dalam pengukuran, yaitu melaksanakan tugas dengan tepat dan tanggung jawab yang dilaksanakan organisasi secara tepat.

a. Melaksanakan tugas dengan tepat

Tidak ada perbandingan pada indikator ini hasil wawancara dari keseluruhan informan bahwa pelaksana sudah sesuai dalam pelaksanaan tugasnya dengan tepat, dengan adanya beberapa pihak terkait, adanya keterangan teknis pengerjaan dilapangan, sampai kepada pengawasan. Hasil observasi yang dilakukan dilapangan sudah sesuai namun belum maksimal karena masih belum meratanya kegiatan normalisasi irigasi. Selain itu tersedianya papan proyek disetiap kegiatan program tersebut dan adanya tim pengawas dalam kegiatan.

Pada indikator melaksanakan tugas dengan tepat sudah tercapai meskipun belum maksimal. Hal ini didapat dari hasil wawancara dan observasi dilapangan menujukkan secara tugas dan fungsi sudah tepat dalam 
pelaksanaan tugas yaitu Pelaksanaan kegiatan dalam program tersebut ada beberapa pihak yang terkait. Pejabat pembuat komitmen merupakan adalah pejabat yang bertanggungjawab atas pelaksanaan pengadaan barang atau jasa. Adanya direksi teknis maka kegiatan tersebut bisa diawasi dengan baik. Tetapi perlu adanya pertimbangan dengan pemerataan kegiatan program tersebut. kejelasan dari setiap kegiatan dapat dilihat oleh masyarakat melalui papan proyek. Papan proyek dalam setiap kegiatan program tersebut untuk dilihat oleh masyarakat bahwa proyek tersebut jelas apakah dari Dinas Pekerjaan Umum Pemataan Ruang Kabupaten Karawang atau dari Provinsi. hal tersebut untuk mengetahui tugas yang dilakukan oleh pelaksana sudah sesuai atau belum.

b. Tanggung jawab yang dilaksanakan organisasi secara tepat

Hasil wawancara beberapa informan terdapat perbandingan antara pemerintah dengan masyarakat, petani, dan gabungan kelompok tani. Pemerintah yaitu Kepala Bidang SDA, Kepala Dinas, Kepala Seksi Perencanaan, dan Camat Pakisjaya bahwa tanggungjawab dalam organisasi sudah tepat. Proses pertanggungjawabannya baik itu berupa membuat berita acara dan laporan-laporan setelah pelaksanaan kegiatan sedangkan menurut masyarakat, petani, dan gabungan kelompok tani bahwa tanggungjawab dalam sebuah organisasi belum tepat karena masih belum bisa menertibkan pada saat dilapangan dan ada desa yang belum ikut serta dalam mengawasi pelaksanaan kegiatan.

Hasil observasi yang dilakukan oleh peneliti bahwa proses pertanggungjawaban dalam organisasi belum sepenuhnya tepat. Seperti halnya dari Dinas PUPR meskipun pertanggungjawaban secara tertulis ada, tetapi pada saat pelaksanaan kegiatan belum maksimal. Selain itu peneliti melihat bahwa pelaksana kegiatan dalam normalisasi irigasi masih kurang rapi untuk hasil galian tanah dan tanggungjawab tiap Desa di Kecamatan Pakisjaya ini belum semua bertanggungjawab dalam pemeliharaan irigasi. Perlunnya peningkatan koordinasi dilakukan oleh Kecamatan dan Desa. 
Dari hasil wawancara dan observasi tersebut dapat diketahui bahwa pada proses pertanggungjawaban ini baik dari Dinas, penyedia jasa dilakukan dengan baik. Namun, masyarakat juga perlu mengetahui yang terjadi dilapangan setelah melaksanakan tugasnya. Seperti pada kegiatan normalisasi dalam hal ini tanggungjawab dari pelaksana belum sesuai dikarenakan tidak dirapikan dan mengganggu jalan umum. Kemudian pada pembangunan infrastruktur jaringan irigasi tidak ada perbaikan-perbaikan yang dilakukan. Atas hal tersebut perlu ditindak lanjuti dengan baik untuk pertanggungjawabannya. Pada proses pertanggungjawaban ini belum tepat.

\section{Ketepatan Dalam Menentukan Pilihan}

Pada kegiatan program yang di lakukan oleh Dinas Pekerjaan Umum dan Penataan Ruang Kabupaten Karwang dalm prosesnya tidak ingin mengalami kesalahan dalam menentukan pilihan. Berkaitan dengan proses kegiatan tersebut terdapat indikator yaitu memilih metode dan perencanaan yang tepat dalam pelaksanaan program. indikator memilih metode dan perencanaan yang tepat kita dapat melihat sejauh mana Dinas Pekerjaan Umum dan Penataan Ruang sudah tepat dalam menentukan pilihan untuk melaksanakan kegiatan yang berkaitan dengan program tersebut.

a. Memilih metode yang tepat

Berdasarkan hasil wawancara dari beberapa informan terdapat perbandingan mengenai metode yang dipilih sudah tepat menurut Kepala Bidang SDA, Kepala Dinas, Kepala Seksi Perencanaan, Camat Pakisjaya, petani di Desa Telukbuyung dan Desa Tanjungbungin, dan masyarakat, sedangkan menurut gabungan kelompok tani seharusnya ada metode lain yang dapat mengatasi sampah diarea irigasi melalui mesin. Berdasarkan observasi dilapangan bahwa metode yang digunakan dalam program pengembangan dan pengelolaan jaringan irigasi ini sudah tepat, karena normalisasi sering dilakukan di Kecamatan Pakisjaya dan metode tersebut merupakan metode secara umum yang dilakukan pada saat kegiatan normalisasi maupun pembangunan infrastruktur jaringan irigasi. 
Dari hasil wawancara dan observasi yang dilakukan oleh peneliti, maka di dapat bahwa Dinas PUPR Kabupaten Karawang sudah memilih metode dan konsep yang sesuai. Hal ini dapat dilihat dari pelaksanaan normalisasi dengan exavator, kemudian infrastruktur yang dibangun adalah adanya pintu air dan lanning di sisi sepanjang jaringan irigasi, meskipun dalam realisasinya belum merata. Jadi, pada ketepatan dalam menentukan pilihan itu sudah tepat.

\section{Ketepatan Berpikir}

Ketepatan berpikir bisa dilihat dari indikator yaitu kemampuan untuk memahami konsep, metode yang hendak dilaksanakan dalam program dan berpikir sistematis dalam proses evaluasi pelaksanaan program. Berikut ini hasil wawanara peneliti kepada narasumber.

a. Kemampuan untuk memahami konsep dan metode

Hasil wawaancara dengan Kepala Dinas PUPR bahwa konsep dan metode sudah tepat untuk program ini, terutama untuk penyedia jasa yang berpengalaman, adanya program pengembangan dan pengelolaan jaringan irigasi ini menurutnya sudah menjadi kegiatan rutin yang terkonsep dengan matang. Berdasarkan Hasil wawancara oleh Kepala Dinas, Kepala Bidang SDA, Kepala Seksi Perencanaan dan Camat Pakisjaya yang berkaitan dengan kemampuan memahami konsep dan metode pada program tersebut tidak ada perbandingan pendapat pada indikator ini sudah sesuai dengan jenis kegiatan. Adanya panduan untu para pelaksana dan mengadakan pertemuan dengan pihak Kecamatan yang akan dilaksanakan. Adanya acuan mulai dari tahap perencanaan kemudian oleh seksi perencanaan teknis dituangkan kedalam bentuk ketentuan sebagai acuan kerja, RAB, serta kedalam bentuk gambar rencana kerja sebagai panduan bagi penyedia jasa dan pengawas lapangan.

Berdasarkan observasi yang dilakukan oleh peneliti didapat bahwa untuk memahami konsep tersebut melihat acuan yang telah dibuat, tentunya rancangan tersebut sudah melihat dari situasi dan kondisi yang terjadi dilapangan. Dalam ketentuan sebagai acuan kerja disini merupakan tanggungjawab terhadap yang perencanaan yang sudah ditentukan. 
b. Proses evaluasi

Hasil wawancara dari beberapa informan adanya perbedaan pendapat antara Pemerintah dan masyarakat. Hasil wawancara dengan Kepala Dinas, Kepala Bidang SDA, Kepala seksi perencanaan, dan Camat Pakisjaya menyatakan sudah tercapai dikarenakan evaluasi dilaksanakan rutin pada setiap kegiatan untuk mengetahui kekurangan dan hambatan pada saat pelaksanaan kegiatan, sedangkan menurut masyarakat, Petani, dan Gapoktan bahwa evaluasi belum terelisasikan dengan baik karena belum ada perbaikan mengenai infrastruktur yang rusak. Berdasarkan observasi yang diamati oleh peneliti bahwa evaluasi dalam setiap pelaksanaan kegiatan program perlu dilakukan, karena proses evaluasi bertujuan memberikan gambaran setelah program kegiatan tersebut dilakukan. Proses evaluasi tersebut belum terelisasikan dengan tepat karena kondisi dilapangan tetap kekeringan irigasi dan pembangunan infrastruktur belum merata.

Berdasarkan hasil wawancara dan observasi yang dilakukan peneliti dapat dipahami bahwa proses evaluasi dalam pelaksanaan pada setiap kegiatan program pengembangan dan pengelolaan jaringan irigasi terus dilakukan, hal ini dapat dilihat dari pasca pelaksanaan kegiatan serah terima sampai dengan 6 bulan kedepan, bahwa setiap ada infrastruktur yang dibangun (pelaksanaan program) dalam kondisi baik dan sesuai perencanaan maka kegiatan tersebut berhasil, jika ada kerusakan sebelum waktu yang telah di tentukan, maka penyedia jasa yang bertanggung jawab, tetapi dalam pengaplikasiannya masih belum optimal karena, masih ada evaluasi dalam program tersebut yang harus dilakukan agar tidak terjadi lagi. Seperti halnya belum adanya tindak lanjut untuk memperbaiki kerusukan-kerusakan pada infrastruktur irigasi dan pada kegiatan normalisasi belum mempertimbangkan hambatan-hambatan yang terjadi dilapangan Atas hal tersebut maka peneliti menyimpulkan hasil wawancara yang berkaitan dengan proses evaluasi belum tercapai. 


\section{Ketepatan Dalam Melakukan Perintah}

Kaitannya dengan program yang dilakukan oleh Dinas Pekerjaan Umum dan Penataan Ruang Kabupaten Karawang dalam pengelolaan irigasi tersebut harus mempunyai perintah yang jelas kepada siapa pengerjaan normalisasi, rehabilitas itu dilakukan. Pada ketepatan dalam melakukan perintah tersebut untuk mengetahui bagaimana untuk menentukan teknisi dalam pelaksanaan program yang dilakukan oleh Dinas PUPR tersebut.

a. Menentukan teknisi dengan tepat

Hasil wawancara beberapa informan dari pihak Pemerintah saja seperti Kepala Dinas, Kepala Bidang SDA, Kepala Seksi Perencanaan dan Camat tersebut tidak ada perbandingan dapat disimpulkan bahwa dalam menentukan teknisi untuk melakukan perintah yang akan dilaksanakan sudah tepat, hal ini dapat dilihat Dinas PUPR memilih yang terbaik untuk proses pelaksanaan kegiatan dengan cara mempunyai syarat dan kriteria tertentu untuk penyedia jasa.

Berdasarkan observasi yang dilakukan oleh peneliti bahwa adanya kriteria tertentu untuk penyedia jasa dalam melakukan program tersebut, adanya kriteria dan syarat tertentu untuk meyakinkan bahwa pelaksanaan kegiatan dapat berjalan dengan lancar. Kriteria tertentu menunjukkan pelaksana sudah menguasai konsep dan metode yang hendak dilaksanakan. Jadi, ketepatan dalam melakukan perintah sudah sesuai dengan tolak ukur keberhasilan efektivitas dalam pelaksanaan program.

Berdasarkan hasil wawancara dan observasi tersebut maka peneliti menganalisis pada indikator menentukan teknisi sudah tepat hal ini dapat dilihat dari Menentukan perintah dengan tepat dilihat dari teknisi yang terbaik. Dalam hal ini, pada pelaksanaan kegiatan program harus mempunyai kemampuan sesuai bidangnya. Pada penentuan teknisi ini Dinas Pekerjaan Umum dan Penataan Ruang Kabupaten Karawang mempunyai kriteria tersendiri untuk memilih teknisi yang terbaik agar perintah dilaksanakan berjalan dengan lancar. Melihat pada penyedia jasa, yaitu mempunyai kriteria umum yang standar. Misalnya wajib memiliki kualifikasi yang disyaratkan dan 
memiliki tenaga ahli dibidang yang sesuai dengan kegiatan program tersebut dan bisa dibuktikan dengan surat keterangan (SKA/SKP).

\section{Ketepatan Dalam Menentukan Tujuan}

Ketepatan dalam melakukan tujuan bisa dilihat dari indikator adanya ketentuan dan peraturan yang sebagai acuan untuk menjalankan tugasnya, selanjutnya dapat dilihat dari proses pengawasannya agar mengetahui kegiatan tersebut lancar atau tidak. Karena dalam melakukan tujuan harus sesuai dengan rencana yang telah ditetapkan.

a. Adanya ketentuan dan peraturan

Dari hasil wawancara beberapa informan terdapat perbandingan yaitu pada pihak Pemerintah seperti Kepala Dinas, Kepala Bidang SDA, Kepala seksi perencanaan dan Camat Pakisjaya bahwa adanya ketentuan dan peraturan baik dari Pusat maupun Daerah sedangkan hasil wawancara dari masyarakat, petani, dan Gapoktan bahwa adanya ketentuan dan peraturan namun masyarakat belum mengetahui mengenai program pengembangan dan pengelolaan jaringan irigasi tersebut.

Berdasarkan observasi peneliti bahwa ketentuan dan peraturan dibuat untuk mengetahui batasan-batasan yang hendak dilakukan. Pada program kegiatan tersebut ketentuan dibuat oleh Dinas Pekerjaan Umum dan Penataan Ruang Kabupaten Karawang ataupun peraturan dari Pemerindah Daerah Kabupaten Karawang. Ketentuan yang dibuat dari Dinas itu sendiri sudah jelas dapat dilihat dari Surat Perintah Kerja dan papan proyek yang ada. Adanya ketentuan ini menjadi tujuan dalam segala kegiatan program yang dilaksanakan. Pada indikator ketentuan dan peraturan sudah tepat.

Berdasarkan hasil wawancara dan observasi yang dilakukan maka peneliti menyimpulkan pada indikator adanya ketentuan dan peraturan belum tercapai hal ini dapat dilihat dari komunikasi kepada masyarakat mengenai program ini belum tepat. Meskipun sudah ada ketentuan dan peraturannya namun realisasinya belum tercapai. 


\section{b. Proses pengawasan}

Pihak Pemerintah yaitu Kepala Dinas, Kepala Bidang SDA, Kepala seksi perencanaan, dan Camat Pakisjaya bahwa pengawasan sudah tepat hal ini dapat dilihat dari pengawasan dalam kegiatan setiap program pihak-pihak terkait juga berperan. Adanya seksi pengawasan di bidang SDA, Pemerintah setempat, dan masyarakat sedangkan menurut masyarakat, petani, dan gapoktan bahwa pengawasan belum maksimal karena pada saat pelaksanaan kurang tertib, pengawasan dilakukan dengan waktu yang singkat untuk mengontrol pelaksanaan kegiatan sehingga belum bisa mengetahui masalah yang terjadi pada saat pelaksanaan kegiatan.

Dari observasi yang peneliti amati dilapangan bahwa proses pengawasan sudah dilakukan namun belum maksimal karena ada beberapa Desa yang belum melakukan pengawasan dengan baik terhadap kerusakan-kerusakan infrastruktur jaringan irigasi untuk mengetahui penyebab kerusakan tersebut, selanjutnya pada saat pelaksanaan normalisasi irigasi pengawasan dilakukan belum baik karena belum bisa tertib dan teratur penempatan hasil tanah galian ada yang diambil oleh masyarakat dan ada yang dibiarkan. Pengawasan oleh Dinas terhadap waker setempat belum maksimal pada pelaksanaan pemeliharaan jaringan irigasi.

Berdasarkan hasil wawancara dan observasi tersebut maka didapat pengawasan yang dilakukan oleh berbagai pihak sudah dilakukan, baik itu pengawasan oleh Dinas dan Pemerintah setempat. Namum dalam pelaksanaannya belum maksimal, dikarenakan pengawasan yang dilakukan tidak teratur seperti pada pelaksanaan rehabilitas infrastruktur jaringan irigasi kurang tegas kepada masyarakat setempat untuk tidak merusak fasilitas, kemudian pada kegiatan normalisasi irigasi tersebut dari Pemerintah Desa masih ada yang belum melakukan pengawasan hal ini terjadi karena belum ada gerakan untuk ikut serta mengawasi pelaksanaan tersebut. Pada indikator proses pengawasan disini belum tepat. 


\section{Ketepatan Sasaran}

Untuk melihat program yang dijalankan oleh Dinas Pekerjaan Umum dan Penataan Ruang dalam pengelolaan irigasi ini maka terdapat indikator adanya perintah yang jelas yaitu berupa peraturan sebagai tujuan utama diadakannya program tersebut, selanjutnya adalah perencanaan yang matang agar dalam pelaksanaannya dapat berjalan lancar dan sesuai rencana dan perintah, dan melihat dari kepuasan masyarakat terhadap program yang dilaksanakan oleh Dinas PUPR tersebut.

a. Perintah yang jelas

Hasil wawancara dari beberapa informan antara pihak Pemerintah dan masyarakat adanya perbedaan pendapat mengenai indikator ini dari pihak Pemerintah yaitu Kepala Dinas, Kepala Bidang SDA, Kepala Seksi Perencanaan dan Camat Pakisjaya bahwa sudah sesuai hal ini dapat dilihat dari adanya peraturan daerah sehingga program pengembangan dan pengelolaan jaringan irigasi ada, sedangkan dari pihak masyarakat, petani, dan gabungan kelompok tani bahwa perintah yang jelas belum tepat dikarenakan belum adanya informasi mengenai program yang dilakukan dari Dinas Pekerjaan Umum dan Penataan Ruang Kabupaten Karawang. Hasil observasi oleh peneliti dilapangan yaitu belum ada sosialisasi mengenai program pengembangan dan pengelolaan jaringan irigasi yang dilaksanakan oleh Dinas PUPR tersebut sehingga dalam peraturan yang mencakup irigasi masyarakat belum mengetahui.

Berdasarkan hasil wawancara dan observasi maka dapat dipahami bahwa masyarakat belum mengetahui secara rinci mengenai peraturan tersebut dan masyarakat belum mengetahui program yang dijalankan oleh Dinas Pekerjaan Umum dan Penataan Ruang Kabupaten Karawang mengenai jaringan irigasi ini. Seharusnya ada komunikasi atau pendampingan bagi para petani untuk mengetahui sasaran dari program tersebut. Program pun perlu di sosialisasikan kepada masyarakat. Pada indikator perintah yang jelas ini belum tepat, dikarenakan masyarakat tidak mengetahui program yang 
dilaksanakan oleh Dinas Pekerjaan Umum dan Penataan Ruang Kabupaten Karawang yang berkaitan dengan jaringan irigasi.

b. Perencanaan yang matang

Dari beberapa hasil wawancara dengan informan terdapat perbedaan pendapat antara pihak Pemerintah dan kalangan masyarakat. Hasil wawancara oleh Kepala Dinas, Kepala Bidang SDA, Kepala Seksi Perencanaan dan Camat Pakisjaya pada indikator perencanaan yang matang sudah tepat hal ini dapat dilihat setiap kegiatan yang dilakukan dilihat dari tingkat kerusakannya, adanya masukan dari tingkat musrenbang kecamatan dan mempertimbangkan biaya yang dikeluarkan sedangkan dari pihak masyarakat, gapoktan, dan petani berpendapat bahwa perencanaan yang matang belum tepat karena aspirasi yang diajukan saat ini belum cepat tanggap untuk direalisasikan dan hanya melihat dari tingkat kepentingannya saja. Berdasarkan hasil observasi yang diamati peneliti bahwa proses perencanaan diseluruh Desa yang ada di Kecamatan Pakisjaya belum dilakukan sepenuhnya, tidak rutin dalam tiap tahun sehingga masyarakat tidak dapat mengusulkannya ke setiap Desa.

Berdasarkan hasil wawancara dan observasi bahwa Dinas Pekerjaan Umum dan Penataan Ruang Kabupaten Karawang memilih rencana agar matang dengan menyeleksi apa saja yang menjadi urgensi untuk ditindak lanjuti. Adanya usulan-usulan dari masyarakat belum dilakukan dengan baik. Hal ini dapat dilihat dari Musrenbang Kecamatan Pakisjaya yang masuk ke Dinas tetapi hanya beberapa yang dilakukan karena hanya melihat dari tingkat urgensinya saja tidak merencanakan apa yang seharusnya tepat sasaran dalam program ini agar tidak terjadi kekeringan terus-menerus. Pada indikator perencanaan yang matang ini belum tepat sasaran.

c. Kepuasan masyarakat

Berdasarkan hasil wawancara beberapa informan tersebut adanya perbandingan oleh Kepala Dinas, Kepala Bidang SDA, dan Kepala Seksi Perencanaan berpendapat selama ini sudah terpenuhi karena sering dilakukan kegiatan-kegiatan untuk menunjang kebutuhan air bagi petani sedangkan dari 
Camat Pakisjaya, masyarakat, Gapoktan, dan petani berpendapat bahwa belum terpenuhi karena masih ada beberapa kegiatan program yang belum dilakukan dengan merata di Desa yang ada di Kecamatan Pakisjaya. Berdasarkan observasi dilapangan yang diamati oleh peneliti bahwa masih ada petani yang mengeluh karena kekurangan air dan pembangunan irigasi yang kurang memadai, infrastruktur jaringan irigasi tidak terawatt dengan baik sehingga hal tersebut menjadi tanggungjawab pemerintah setempat baik di Kecamatan maupun Desa.

Berdasarkan hasil wawancara dan observasi maka dapat dipahami kepuasan masyarakat Kecamatan Pakisjaya belum terpenuhi kebutuhan airnya, hal ini dapat dilihat dari belum meratanya air yang masuk di beberapa Desa Kecamatan Pakisjaya. Adanya program pengembangan dan pengelolaan jaringan irigasi ini untuk memberikan dampak positif untuk masyarakat, terutama untuk kebutuhan Petani. Namun, saat ini pihak pengelola menjadikan air irigasi untuk diperjual belikan kepada swasta seperti PDAM. Sehingga sasaran tersebut berubah fungsi bukan untuk kebutuhan petani. Sehingga untuk masyarakat dan petani di Kecamatan Pakisjaya belum terpenuhi kebutuhan airmya dikarenakan air tidak sampai ke hilir. Air irigasi yang tidak merata ini terjadi karena pengelolaan pada pintu airnya kurang maksimal.

\section{KESIMPULAN}

Berdasarkan penelitian yang telah dilakukan bahwa efektivitas program pengembangan dan pengelolaan jaringan irigasi oleh Dinas Pekerjaan Umum dan Penataan Ruang di Kecamatan Pakisjaya Kabupaten Karawang memiliki kemampuan untuk mencapai efektivitas pada program pengelolaan dan pengembangan jaringan irigasi yaitu belum efektif. Hal ini dapat dilihat dari indikator dari setiap dimensi pada teori yang digunakan ada beberapa yang belum tercapai. 


\section{DAFTAR PUSTAKA}

Andriani, \& dkk. (2020). Metode Penelitian Kualitatif dan Kuantitatif.

Yogyakarta: CV. Pustaka Ilmu

BERSEKANEWSs.id. (2019, September 4). Ratusan Hektar Sawah Di Pakisjaya Karawang Kekeringan, Ini Penyebabnya. Retrieved Januari 13, 2021, from bersekanews.id: https://bersekanews.id/karawang/ratusan-hektarsawah-di-pakisjaya-karawang-kekeringan-ini-penyebabnya.aspx

Kordi K., M. G. H. \& Tancung, A. B., (2007). Pengelolaan Kualitas Air. 1st ed. Jakarta: PT Rineka Cipta.

LISTYANINGTYAS, E. F. F. (2012). Efektivitas Pelaksanaan Pemeriksaan dalam Rangka Meningkatkan Penerimaan Negara dari Sektor Pajak (Studi Kasus di KPP Tulungagung). Jurnal Akuntansi AKUNESA, 1(1).

Makmur., (2015). Efektivitas Kebijakan Kelembagaan Pengawasan. 2nd ed. Bandung: PT Refika Aditama.

Sugiyono, (2020). Metode Penelitian Kualitatif. 3 ed. Bandung: Alfabeta.

Wibowo. (2018). Tesis. Retrieved Mei 13, 2020, from iptek.its.ac.id: http://iptek.its.ac.id/index.php/jats/article/download/2793/2754

Dinas PUPR Kabupaten Karawang

Peraturan Daerah Kabupaten Karawang Nomor 2 Tahun 2013 Tentang Rencana Tata Ruang Wilayah 